\title{
Stem cell transplantation for hemoglobinopathy Vila Real
}

\section{Justin Hasenkamp ${ }^{1}$ (D) · Joachim Riggert ${ }^{2} \cdot$ Wolfram Jung $^{1} \cdot$ Hristo Boyadzhiev $^{1} \cdot$ Jakob Valk $^{2} \cdot$ Lorenz Trümper $^{1}$. Gerald Wulf ${ }^{1}$}

Received: 30 April 2020 / Accepted: 26 August 2020 / Published online: 3 September 2020

(C) The Author(s) 2020

Dear Editor,

Hemoglobinopathy Vila Real (HbVR) is a rare congenital disease caused by a hemoglobin beta chain $\mathrm{P} 36 \mathrm{H}$ mutation $[1,2]$. The hemoglobin variant is associated with increased oxygen affinity, resulting in reduced oxygen delivery to target tissues, painful hypoxic organ damage, and compensatory erythrocytosis. Diagnosis is based on clinical presentation of erythrocytosis with high oxygen saturation and tissue hypoxia, to be confirmed by hemoglobin sequence analysis. Hitherto, therapy of symptomatic patients consists of phlebotomy plus transfusions to alleviate symptoms.

We report the case of a 47-year-male diagnosed with HbVR 10 years before in the work-up of erythrocytosis. When the patient experienced progressive pain attacks in the head, testis, and muscles, phlebotomy and transfusions of cumulative 168 erythrocyte concentrates were started, without amelioration in the recent year. As yet, antibodies against red blood cells were not detected to this point of time.

Bone marrow transplantation (BMT) was offered to the patient to avoid the long-term complications of transfusion dependency and disease-related end-organ damage [3]. To avoid disease-related ischemic injury and reperfusion events during transplantation, similar to symptoms of sickle cell crisis, but with different pathomechanism, complete blood exchanges were performed before the preparative regimen was started. Following conditioning with thiotepa, fludarabine, and treosulfan, bone marrow from a HLA-matched unrelated

Justin Hasenkamp

j.hasenkamp@med.uni-goettingen.de

1 Hematology and Medical Oncology, University Medicine Goettingen, Robert-Koch-Str. 40, D-37099 Goettingen, Germany

2 Department of Transfusion Medicine, University Medicine Goettingen, D-37099 Goettingen, Germany donor containing $1.5 \times 10^{8}$ leukocytes $/ \mathrm{kg}$ body weight (BW) was transfused after depletion of erythrocytes and plasma. Graft-versus-host-disease prophylaxis consisted of anti-thymocyte-globulin, cyclosporin A (CSA), and mycophenolate mofetil. During aplasia, CMV reactivation and a sepsis responded to treatment. Leukocyte engraftment occurred 21 days post-BMT with complete donor chimerism. The patient remained dependent on transfusion for erythrocytes and thrombocytes. Bone marrow investigation on day 27 revealed graft failure suspected to be due to the low cell count in the transplanted product. Fifty-one days post-BMT, we transfused $4.0 \times 10^{6} \mathrm{CD} 34+$ cells $/ \mathrm{kg}$ BW purified from the mobilized peripheral blood stem cells of the original donor. From day 8 after the stem cell boost, the patient was transfusion independent and the reticulocytes rose with continuous complete donor chimerism.

Further complications post-BMT resembled typical sickle cell complications: seizures and visual impairments compatible with posterior reversible encephalopathy syndrome (PRES) by NMR imaging (Fig. 1), diabetes insipidus centralis due to the PRES or CSA, and diabetes insipidus renalis due to foscarnet turned out to be manageable. Following recovery, further followup was uneventful through 2.5 years, without immunosuppression and according to hemoglobin analysis complete correction of the hemoglobinopathy.

This is the first report of allogeneic hematopoietic stem cell transplantation (HSCT) for a patient with HbVR, a condition associated with severely reduced quality of life and high prevalence of end-organ complications. The curative potential of HSCT in hemoglobinopathies is well-established [3] but is hampered by the dilemma to outweigh the benefits from definite cure versus the transplant-related risks for. Particular in adult patients with advanced disease, comorbidities precipitate complications [4]. PRES is elsewise common in pediatric hemoglobinopathy patients receiving HSCT [5-7]. 


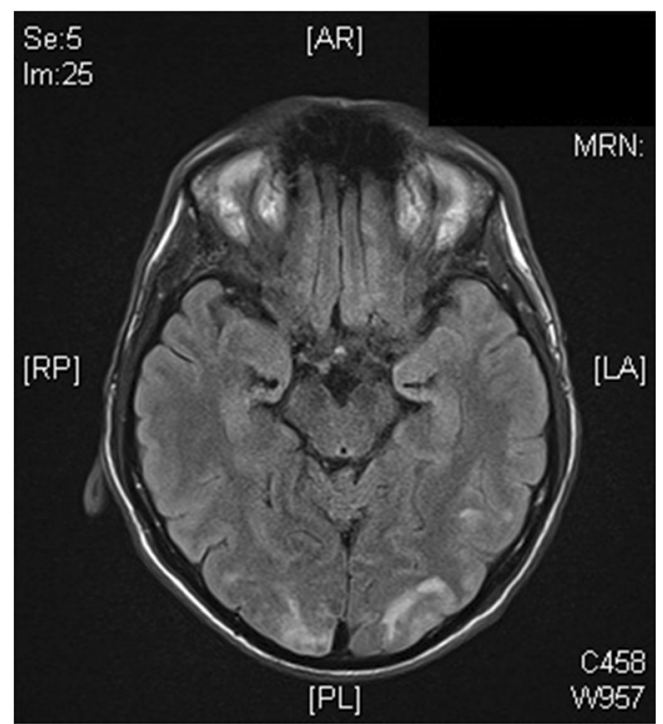

Fig. 1 NRM brain image of the patient 40 days post-BMT with occipital edema compatible with posterior reversible encephalopathy syndrome (PRES)

In summary, the rarity and clinical heterogeneity of HbVR will always demand an individual approach. For severely affected patients, we report HSCT as a successful option.

Authors' contributions All authors have contributed significantly to the paper, read, and approved the final manuscript. JH wrote the manuscript with contribution of GW and JR. JR and JV performed the cell processing described. JH, WJ, HB, LT, and GW were responsible and treated the patient described.

Funding Open Access funding provided by Projekt DEAL.

Data availability "Not applicable" for that section.

\section{Compliance with ethical standards}

Conflicts of interest The authors declare that they have no conflict of interest.

Ethics approval The work abides the ethical rules of the institutional review board (ethic commission) and is compliant to the Declaration of Helsinki.

Consent to participate "Not applicable" for that section.

Consent for publication The patient of the case described has given consent for publication.
Open Access This article is licensed under a Creative Commons Attribution 4.0 International License, which permits use, sharing, adaptation, distribution and reproduction in any medium or format, as long as you give appropriate credit to the original author(s) and the source, provide a link to the Creative Commons licence, and indicate if changes were made. The images or other third party material in this article are included in the article's Creative Commons licence, unless indicated otherwise in a credit line to the material. If material is not included in the article's Creative Commons licence and your intended use is not permitted by statutory regulation or exceeds the permitted use, you will need to obtain permission directly from the copyright holder. To view a copy of this licence, visit http://creativecommons.org/licenses/by/4.0/.

\section{References}

1. Bento MC, Ribeiro ML, Cunha E, Rebelo U, Granjo E, Granado C, Tamagnini GP (2000) Hb Vila Real [beta36(C2)Pro->His]: a newly discovered high oxygen affinity variant. Hemoglobin 24(1):59-63

2. Salzano AM, Carbone V, Pagano L, Buffardi S, De RC, Pucci P (2002) Hb Vila Real [beta36(C2)Pro->His] in Italy: characterization of the amino acid substitution and the DNA mutation. Hemoglobin 26(1):21-31

3. Angelucci E, Matthes-Martin S, Baronciani D, Bernaudin F, Bonanomi S, Cappellini MD, Dalle JH, Di BP, de Heredia CD, Dickerhoff R, Giardini C, Gluckman E, Hussein AA, Kamani N, Minkov M, Locatelli F, Rocha V, Sedlacek P, Smiers F, Thuret I, Yaniv I, Cavazzana M, Peters C (2014) Hematopoietic stem cell transplantation in thalassemia major and sickle cell disease: indications and management recommendations from an international expert panel. Haematologica 99(5):811-820

4. Zama D, Masetti R, Cordelli DM, Vendemini F, Giordano L, Milito G, Franzoni E, Porta F, Prete A, Rondelli R, Pession A (2014) Risk factor analysis of posterior reversible encephalopathy syndrome after allogeneic hematopoietic SCT in children. Bone Marrow Transplant 49(12):1538-1540

5. Gaziev J, Marziali S, Paciaroni K, Isgro A, Di GF, Rossi G, Marziali M, De AG, Alfieri C, Ribersani M, Andreani M, Palmieri MG, Placidi F, Romigi A, Izzi F, Floris R, Mercuri NB (2017) Posterior reversible encephalopathy syndrome after hematopoietic cell transplantation in children with hemoglobinopathies. Biol Blood Marrow Transplant 23(9):1531-1540

6. Raj S, Overby P, Erdfarb A, Ushay HM (2013) Posterior reversible encephalopathy syndrome: incidence and associated factors in a pediatric critical care population. Pediatr Neurol 49(5):335-339

7. Wong R, Beguelin GZ, de LM, Giralt SA, Hosing C, Ippoliti C, Forman AD, Kumar AJ, Champlin R, Couriel D (2003) Tacrolimus-associated posterior reversible encephalopathy syndrome after allogeneic haematopoietic stem cell transplantation. $\mathrm{Br}$ J Haematol 122(1):128-134

Publisher's note Springer Nature remains neutral with regard to jurisdictional claims in published maps and institutional affiliations. 